IN F O R M A I I A

Jurnal Informatika, Manajemen Dan Komputer Vol. 9 No. 1, Mei 2017

eISSN : 2580-3042

pISSN : 1979-0694

\title{
PENENTUAN ATURAN ASOSIASI PADA TRANSAKSI PEMINJAMAN BUKU MENGGUNAKAN ALGORITMA FP-GROWTH
}

\author{
Elwani \\ Akademi Manajemen Informatika dan Komputer (AMIK) Dumai \\ Jl. Utama Karya Bukit Batrem, Dumai, Kode Pos : 28811 \\ e-mail :elwani2203@gmail.com
}

\begin{abstract}
ABSTRAK
Tujuan dari penelitian ini dapat membantu Perpustakaan STMIK - AMIK Dumai untuk mengambil kesimpulan menentukan jenis Buku yang paling banyak diminati oleh mahasiswa. Istilah Data mining dan knowledge discovery in database (KDD) sering kali digunakan secara bergantian untuk menjelaskan proses penggalian informasi tersembunyi dalam suatu basis data yang besar. Penelitian ini dilakukan untuk mempelajari Data mining merupakan proses untuk mendapatkan informasi yang berguna dari gudang basis data yang berupa ilmu pengetahuan. Penelitian ini melakukan analisa data dengan menggunakan Data mining dan metode algoritma FP-Growth dan Tools Rapidminer studio7.3. Algoritma FP-Growth menganalisis data transaksi peminjaman buku untuk mengetahui dalam perpustakaan. Hasil algoritma FP-Growth dapat menemukan rule atau knowledge untuk menganalisa strategi dalam menentukan transaksi peminjaman buku dan dapat digunakan untuk proses ekstraksi rule atau knowledge yang dihasilkan. Association rule adalah salah satu teknik utama dalam Data mining dan merupakan bentuk yang paling umum dipakai dalam menemukan pattern atau poladari suatu kumpulan data. Berdasarkan hasil pengujian dan analisa Assoction Rule menggunakan Algoritma FP-Growth dan Tools Rapidminer Studio 7.3. Jadi jumlah Rules keseluruhan yang telah diproses adalah 7 keputusan atau pengetahuan baru dengan nilai kombinasi 12 jenis buku, nilai Support A (\%) terendah adalah 0,143 dengan Confidence $\geq 50 \%$ "Yes" dan $\leq 50 \%$ "No".
\end{abstract}

Kata Kunci: Knowledge Discovery in Database (KDD), Data mining, Fp-Growth, Association rule,

\section{PENDAHULUAN}

Perkembangan teknologi informasi memberikan kontribusi pada cepatnya pertumbuhan jumlah data yang dikumpulkan dalam basis data berukuran besar. Perpustakaan merupakan salah satu fasilitas penyedia informasi, sumber ilmu pengetahuan, dan sarana penunjang proses kegiatan belajar mengajar bagi para pengguna untuk mendapatkan informasi yang diinginkan (Wandi, Rully, Hendrawan, dan Mukhlason., 2012).

Data semakin lama akan bertambah semakin banyak. Jika di biarkan saja, maka data-data transaksi tersebut hanya menjadi sampah yang tidak berarti. Dengan adanya dukungan perkembangan teknologi semakin berkembang pula kemampuan dalam mengumpulkan dan mengolah data. Data mining sering juga disebut knowledge discovery in database (KDD), adalah kegiatan yang meliputi pengumpulan, pemakaian, data historis untuk menentukan keteraturan, pola atau hubungan dalam set data yang berukuran besar. Keluaran dari Data mining bisa dipakai untuk memperbaiki pengambialan keputusan dimasa depan Algoritma Fp-Growth adalah algoritma yang peling terlkenal unuk menemukan pola frekuensi tinggi. Algoritma apriori dibagi menjadi beberapa tahap disebut narasi atau pass. Pembentukan kandidat itemsets, kandidat k-itemsets dibentuk dari kombinasi (k-1) - itemsets yang didapat dari iterasi sebelumnya. Satu cara dari algoritma $F p$-Grouwth adalah adanya pemangkasan kandidat $\mathrm{k}$-itemset yang subset-nya yang berisi k-1 item tidak termasuk dalam pola frekuensi tinggi dengan panjang k-1(Sari. 2015).

Penelitian ini akan menggunakan Tools RapidminerStudio 7.3 yang akan digunakan untuk melakukan analisis data pengolahan transaksi dalam peminjaman buku data sehingga dapat mengetahui secara cepat dan mudah. 
I N F O R M A T I K A

Jurnal Informatika, Manajemen Dan Komputer Vol. 9 No. 1, Mei 2017

eISSN : 2580-3042

pISSN : 1979-0694

\subsection{Perumusan Masalah}

Berdassarkan latar belakang diatas, maka dapat dirumuskan permasalahaannya sebagai berikut

1. Bagaimana mengaplikasikan Data mining menggunakan Algoritma FP-Growth untuk menentukan aturan Asosiasi pada transaksi peminjaman buku?

2. Bagaimana Menerapkan Tools Tools RapidminerStudio 7.3 pada Perpustakaan STMIK - AMIK Dumai transaksi peminjaman buku dengan Algoritma FPGrowth.

\subsection{Batasan Masalah}

Permasalahan dalam penelitian ini dibatasi pada beberapa hal yaitu:

1. Implementasi ini Tools RapidminerStudio 7.3 akan digunakan untuk mengelompokkan data jenis buku.

2. Tools Rapidminer Studio 7.3 digunakan untuk melakukan analisis data buku

3. Software pengujian analisis data yang akan digunakan adalah Tools Rapidminer Studio 7.3 .

\subsection{Tinjauan pustaka}

\section{Defenisi Knowledge Discovery in Database (KDD)}

Data mining adalah bagian integral dari penemuan pengetahuan dalam database (KDD), yang merupakan proses keseluruhan mengubah data mentah menjadi informasi yang bermanfaat, seperti yang ditunjukkan pada (Eko $\mathrm{N}$

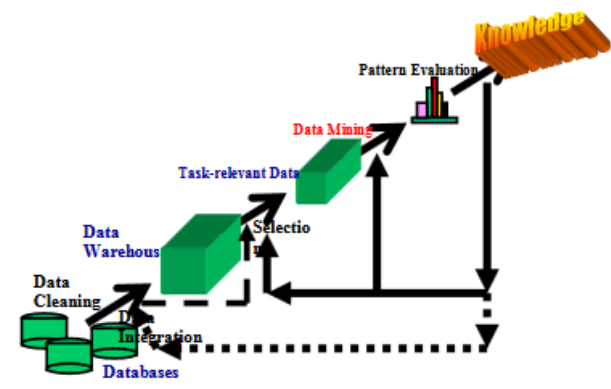

Gambar 1 Proses Penemuan Pengetahuan

Proses KDD ini terdiri dari serangkaian langkah-langkah transformasi, dari proses data preprocessing dan proses data postprocessing dari data yang merupakan hasil penggalian. Karena banyak cara data dapat dikumpulkan dan disimpan, maka proses pengolahan data mungkin akan melelahkan dan memakan waktu yang lama dalam keseluruhan proses penemuan pengetahuan (Wahyudi,

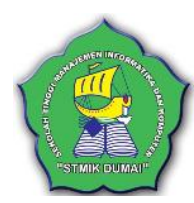

2013). Terdapat empat tugas utama Data mining seperti terlihat pada gambar 2 yaitu :

1. Predictive Modelling

Predictive modelling digunakan untuk membangun sebuah model untuk target variable sebagai fungsi dari explanatory variable. Predictive modelling dibagi menjadi dua tipe yaitu : Classification digunakan untuk memprediksi nilai dari target variable yang discrete (diskrit) dan regression digunakan untuk memprediksi nilai dari target variable yang continue (berkelanjutan).

2. Association Analysis

Association analysis digunakan untuk menemukan aturan asosiasi yang memperlihatkan kondisi-kondisi nilai atribut yang sering muncul secara bersamaan dalam sebuah himpunan data.

3. Cluster Analysis

Tidak seperti klasifikasi yang menganalisa kelas data obyek yang mengandung label. Clustering menganalisa objek data tanpa memeriksa kelas label yang diketahui. Label- label kelas dilibatkan di dalam data training. Karena belum diketahui sebelumnya. Clustering merupakan proses pengelompokkan sekumpulan objek yang sangat mirip.

4. Anomaly Detection

Anomaly detection merupakan metode pendeteksian suatu data dimana tujuannya adalah menemukan objek yang berbeda dari sebagian besar objek lain. Anomaly dapat di deteksi dengan menggunakan uji statistik yang menerapkan model distribusi atau probabilitas untuk data.

\section{Definisi Data mining}

Data mining didefinisikan sebagai proses menemukan pola-pola dalam data. Pola yang ditemukan harus penuh arti dan pola tersebut memberikan keuntungan. Karakteristik Data mining sebagai berikut : (Ahmad. et al .2015)

1. Data mining berhubungan dengan penemuan sesuatu yang tersembunyi dan pola data tertentu yang tidak diketahui sebelumnya.

2. Data mining biasa menggunakan data yang sangat besar. Biasanya data yang besar digunakan untuk membuat hasil lebih dipercaya.

3. Association rule mining adalah teknik mining untuk menemukan aturan assosiatif antara suatu kombinasi item. Contoh dari 
INFORM T IK A

Jurnal Informatika, Manajemen Dan Komputer Vol. 9 No. 1, Mei 2017

eISSN : 2580-3042

pISSN : 1979-0694

aturan assosiatif dari analisa pembelian di suatu pasar swalayan adalah bisa diketahui berapa besar kemungkinan seorang pelanggan membeli roti bersamaan dengan susu.

4. Classification adalah proses untuk menemukan model atau fungsi yang menjelaskan atau membedakan konsep atau kelas data, dengan tujuan untuk dapat memperkirakan kelas dari suatu objek yang labelnya tidak diketahui.

5. Decision tree adalah salah satu metode classification yang paling populer karena mudah untuk diinterpretasi oleh manusia. Setiap percabangan menyatakan kondisi yang harus dipenuhi dan tiap ujung pohon menyatakan kelas data.

6. Clustering, clustering melakukan pengelompokan data tanpa berdasarkan kelas data tertentu. Bahkan clustering dapat dipakai untuk memberikan label pada kelas data yang belum diketahui itu. Karena itu clustering sering digolongkan sebagai metode unsupervised learning.

7. Neural Network, jaringan syaraf buatan yang terlatih dapat dianggap sebagai pakar dalam kategori informasi yang akan dianalisis. Pakar ini dapat digunakan untuk memproyeksi situasi baru dari ketertarikan informasi. bervariasi (Ahmad. et all. 2015). Selain defenisi tersebut, beberapa defenisi juga diberikan seperti tertera di bawah ini:

a. Data mining adalah serangkaian proses untuk menggali nilai tambah dari suatu kumpulan data berupa pengetahuan yang selama ini tidak diketahui secara manual.

b. Data mining adalah analisis otomatis dari data yang berjumlah besar atau kompleks dengan tujuan menemukan pola atau kecenderungan yang penting yang biasanya tidak disadari keberadaannya. (Sari. 2015).

1. Data mining merupakan suatu proses otomatis terhadap data yang sudah ada.

2. Data yang akan diproses berupa data yang sangat besar.

3. Tujuan dari Data mining adalah mendapatkan hubungan atau pola yang mungkin memberikan indi

4. kasi yang bermanfaat. (Dewi P. S. 2015).

\section{Association rules}

Association rule (aturan asosiatif) adalah salah satu teknik utama dalam Data mining dan merupakan bentuk yang paling

umum dipakai dalam menemukan pattern atau poladari suatu kumpulan data. Association rule berusaha menemukan aturan-aturan tertentu yang mengasosiasikan data yang satu dengan data yang lain.Untuk mencari association rule dari suatu kumpulan data, pertama-tama harus dicari lebih dulu yang disebut "frequent itemset" (sekumpulan item yang sering muncul bersamaan). barang tertentu (Diki A. Nofriandi. 2016). adalah antara $0-$ $100 \%$. Support dari suatu association rule adalah proporsi dari transaksi dalam database yang mengandung $\mathrm{A}$ dan $\mathrm{B}$, yaitu:

$$
=\frac{\begin{array}{c}
\text { support }=P(A \cap B) \\
\text { jumlah transaksi yang mengandung } A \text { dan } B
\end{array}}{\text { jumlah total transaksi }}
$$

Confidence dari association rule adalah ukuran ketepatan suatu rule, yaitu persentase transaksi dalam database yang mengandung A dan mengandung

B.

\section{Confidence $=$ jumlah transaksi yang mengandung $A$ dan $B$} jumlah total transaksi

\section{Algoritma FP - Growth \\ a. Defenisi FP-Tree}

FP-Tree merupakan struktur penyimpanan data yang dimampatkan. $F P$ treedibangun dengan memetakan setiap data transaksi ke dalam setiap lintasan tertentu dalam FP-tree. Karena dalam setiap transaksi yang dipetakan, mungkin ada transaksi yang memiliki item yang sama, maka lintasannya memungkinkan untuk saling menimpa. Semakin banyak data transaksi yang memiliki item yang sama, maka proses pemampatan dengan struktur data FP-tree semakin efektif. Adapun $F P$ - tree adalah sebuah pohon dengan definisi sebagai berikut:

1. FP-tree dibentuk oleh sebuah akar yang diberi label null, sekumpulan sub-tree yang beranggotakan item-item tertentu, dan sebuah tabel frequent header.

2. Setiap simpul dalam FP-tree mengandung tiga informasi penting, yaitu label item, menginformasikan jenis item yang direpresentasikan simpul tersebut, support count, merepresentasikan jumlah lintasan transaksi yang melalui simpul tesebut, dan pointer penghubung yang menghubungkan simpul-simpul dengan label item sama antar-lintasan, ditandai dengan garis panah putus-putus. 
IN F ORM T I K A

Jurnal Informatika, Manajemen Dan Komputer Vol. 9 No. 1, Mei 2017

eISSN : 2580-3042

pISSN : 1979-0694

\section{b. Defenisi FP-Growth}

FP-Growth adalah salah satu alternatif algoritma yang dapat digunakan untuk menentukan himpunan data yang paling sering muncul (frequent item set) dalam sekumpulan data. Algoritma FP-Growth merupakan pengembangan dari algoritma Apriori. Sedangkan di dalam algoritma FP-Growth tidak dilakukan generate candidate karena $F P$ Growth menggunakan konsep pembangunan tree dalam pencarian frequent itemset (Ikhwan, Dicky, Sriani. 2015). Algoritma FP-Growth merupakan pengembangan dari algoritma Apriori. Sehingga kekurangan dari algoritma Apriori diperbaiki oleh algoritma FP-Growth. Frequent Pattern Growth adalah salah satu alternatif algoritma yang dapat digunakan untuk menentukan himpunan data yang paling sering muncul (frequent itemset) dalam sebuah kumpulan data.

a. Data yang diambil dari Perpustakaan STMIK-AMIK Dumai akan dipilih untuk diambil sebagai sampel data yang akan diolah.

b. Kemudian akan dilakukan proses pengekstrakan menggunakan Tools RapidminerStudio. sehingga akan mendapatkan hasil rule-rule yang di eksekusi aplikasi tersebut.

\section{METODE PENELITIAN}

\subsection{Kerangka Kerja}

Kerangka kerja dalam penelitian ini digambarkan pada gambar 2.1 beriku:

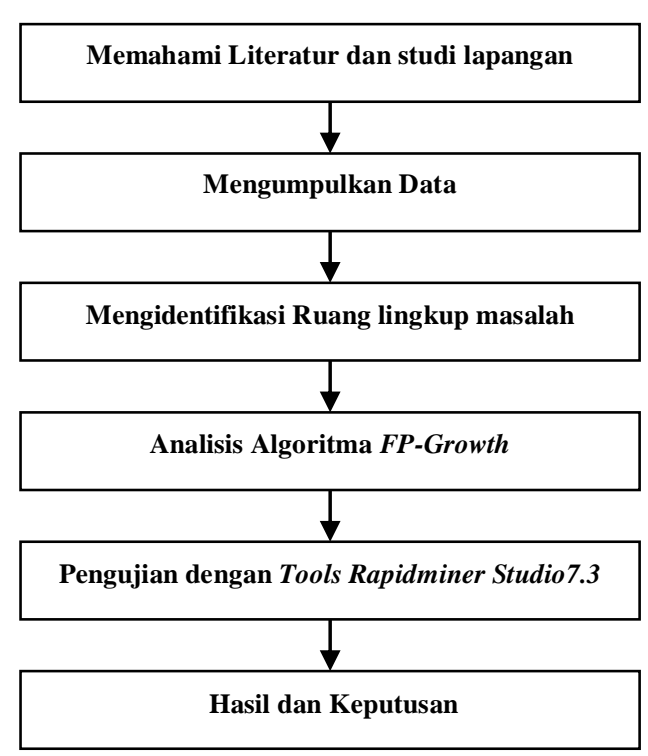

Gambar 2 Kerangka Kerja
Berikut merupakan urutan-urutan langkah kerja berdasarkan gambar 1:

1. Memahami Literatur dan Studi Lapangan Mengumpulkan Literatur berupa jurna nasional maupun internasional untuk dijadikan bahan pembuatan data dan perbandingan. Studi lapangan dalam penelitian ini yaitu melakukan peninjauan atau monitoring ketempat penelitian untuk melakukan pengambilan example data.

2. Mengumpulkan Data

Metode pengumpulan data dilakukan dengan cara melakukan pengamatan langsung ke Perpustakaan STMIK-AMIK Dumai. Selain pengamatan, juga dilakukan wawancara kepada pihak-pihak yang terkait dengan penelitian ini.

3. Mengidentifikasi Masalah dan Menentukan Tujuan

Identifikasi masalah dalam penelitian ini adalah jumlah buku perpustakaan STMIKAMIK Dumai pada data master.

4. Analisis Data dengan data yang akan digunakan

Data yang telah dikumpulkan akan dianalisa. Analisa yang dilakukan pada data (database) menggunakan teknik Tools Rapidminer Studio 7.3 dengan tujuan untuk mendapatkan pengetahuan yang baru (knowledge) berupa informasi banyaknya yang melakukan transaksi peminjaman Buku.

5. Melakukan pengujian dengan Tools RapidminerStudio 7.3.

Pada tahap ini, hasil dari analisis dites kembali atau diuji lagi menggunakan sistem Data mining yang sudah ada. Sistem yang dipakai adalah Tools RapidminerStudio 7.3 yang mampu membaca data dari Microsoft Excel.

\section{HASIL DAN PEMBAHASAN}

\subsection{Sampel Data Yang Digunakan}

Sampel data penelitian yang diambil berdasarkan transaksi peminjaman buku dari tanggal 01 oktober 2016 sampai dengan 13 oktober 2016, hal ini dapat dilihat pada Tabel 1 sampel data transaksi peminjaman buku.

Tabel 1 Frekuensi Kemunculan ke-1 dan Support tiap item

\begin{tabular}{llc}
\hline Kode & Judul Buku & Jumlah \\
\hline MSQL & My SQL untuk Pemula & 7 \\
PTI & Pengenalan Teknologi & 7
\end{tabular}


IN F ORMA T I K A

Jurnal Informatika, Manajemen Dan Komputer Vol. 9 No. 1, Mei 2017

eISSN : 2580-3042

pISSN : 1979-0694

\begin{tabular}{|c|c|}
\hline & Informasi \\
\hline & Sistem Informasi \\
\hline & Penjualan Online \\
\hline & U/Tugas Akhir \\
\hline SIPOU & Php\&My Sql: Pas \\
\hline & Algoritma dan Bahasa \\
\hline ALGOP & Pemrograman \\
\hline & Aplikasi Penjualan \\
\hline APDVX & $\begin{array}{l}\text { Dengan Visual, Xampp } \\
\text { dan ata Report }\end{array}$ \\
\hline APCS3 & Adobe Photoshop CS3 \\
\hline APCS4 & Adobe Photoshop CS4 \\
\hline ANDSI & Analisis dan Disain \\
\hline & Aplikasi Web Database \\
\hline AWBST & Web Store \\
\hline & Bahasa Pemrograman \\
\hline VBNET & Visual Basic Net \\
\hline BSKTI & Buku Sakti \\
\hline PKOM & $\begin{array}{l}\text { Pengenalan komputer } \\
\text { Perancangan \& } \\
\text { Implementasi Sistem }\end{array}$ \\
\hline PIMBS & Basis Data \\
\hline & Prinsip-prinsip \\
\hline PPINF & Informasi \\
\hline & Aplikasi Sms Dengan \\
\hline & Visual Basic 6,0 \& \\
\hline ASVB & Visual Basic 2010+CD \\
\hline & Aplikasi Web Database \\
\hline AWBDS & dan PHP, My SQL \\
\hline ARDM & Arduino itu Mudah \\
\hline & Bahasa Pemrograman \\
\hline VBPOF & Visual Basic Point Of \\
\hline & Belajar Sendiri \\
\hline BSWEB & Pemrograman Web \\
\hline CRPOT & Cristal Report \\
\hline KMAKT & Kamus Akuntansi \\
\hline & Keamanan Sistem \\
\hline KSISI & Informasi \\
\hline & Konsep Sistem \\
\hline KSPK & Pendukung Keputusan \\
\hline & Kumpulan Aplikasi \\
\hline KAINT & Berinternet \\
\hline & Manajemen Proyek \\
\hline & Berbasis Teknologi \\
\hline MPSTI & Infoarmasi \\
\hline MWEB & Membangun Web Site \\
\hline MHADW & Mengenal Hadware \\
\hline & Mengenal Komputer \\
\hline MKFB & For Bergers \\
\hline & Metodologi Analisis \\
\hline MEAD & Data \\
\hline
\end{tabular}

3

2

2

2

2

2

2

2

2

2

2

2

1

1

1

1

1
Pandai Belajar

PBP

Program

Pemograman

PBO Berorientasi Objek 1

PJAVA Pemograman Java

Pengantar Algoritma

ALGOP dan pemograman

PIK $\quad \begin{array}{ll}\text { Pengelolaan Intalasi } \\ \text { Komputer }\end{array}$

Referensi Kamus

RKVB Visual Basic 1

Rekayasa Perangkat

REPEL Lunak

Sisem Pengantar

SPEKO Ekonomi 1

SISBA Sistem Basis Data 1

SISOM Sistem operasi modern 1

SPTA Aplikasi 1

SMSGT Sms Gateway 1

TEKOI dan Informasi 1

Pada tabel 2 dapat dilihat hasil frekuensi kemunculan item transaksi peminjaman buku, lalu dilakukan penentuan support, pada penelitian ini diambil nilai Support count $30 \%$. Nilai Support count akan mempengaruhi item yang akan mempengaruhi item yang akan di analisa ke tahap pembuatan FP-Tree dan dapat kita ketahui nilai support tertinggi serta dapat kita ketahui nilai support yang memenuhi Support count 30\%, maka item yang akan digunakan untuk selanjutnya adalah item yang memenuhi frekuensi $\geq 3$, yaitu pada tabel 2

Tabel 2. Frekunsi Jumlah minimum Support $\mathrm{Ke}-2$

\begin{tabular}{llc}
\hline Kode & Judul Buku & Jumlah \\
\hline \multirow{3}{*}{ MSQL } & My SQL untuk & \\
& Pemula & 7 \\
PTI & Pengenalan & \\
& Teknologi Informasi & 7 \\
& Sistem Informasi & \\
& Penjualan Online & \\
& U/Tugas Akhir & \\
SIPOU & Php\&My Sql: Pas & 3 \\
\hline
\end{tabular}

Setelah dilakukan pemindaian data, pada kemunculan kedua menjadi data transaksi dalam pengolahan Data mining, pada tabel 3 dapat dilihat data transaksi setelah pemindaian dan diurutkan berdasarkan nilai frekuensi. 
IN F ORMA T I K A

Jurnal Informatika, Manajemen Dan Komputer Vol. 9 No. 1, Mei 2017

eISSN : 2580-3042

pISSN : 1979-0694

$\underline{\text { Tabel } 3 \text { Data Transaksi Setelah Pemindaian }}$

\begin{tabular}{cl}
\hline TID & Item set \\
\hline 1 & $\{$ PTI, SIPOU $\}$ \\
2 & $\{$ MSQL $\}$ \\
3 & $\{$ MSQL $\}$ \\
4 & $\{$ MSQL, PTI,SIPOU $\}$ \\
5 & $\{$ MSQL, SIPOU $\}$ \\
6 & $\{$ MSQL, PTI $\}$ \\
7 & $\{$ PTI $\}$ \\
8 & $\{$ MSQL,PTI $\}$ \\
9 & $\{$ MSQL,PTI $\}$ \\
10 & $\{$ PTI $\}$ \\
\hline
\end{tabular}

\subsection{Pembentukan FP-Tree}

Setelah item-item frequent didapat yang memenuhi nilai Support Count maka pembangkitan FP-Tree dapat dilakukan. Data akan diolah secara manual sesuai dengan konsep Data mining dengan menggunakan algoritma frequent pattern growth (FP Growth). Setelah data diurut dapat kita lanjut pada tahap pembangkit FP Tree. Pembacaan TID 1 atau transaksi pertama, lalu dilanjutkan Pembacaan TID 2 (Transaksi kedua), dan dilanjutkan transaksi selanjutnya hingga transaksi terakhir. Pembacaan TID 1

Pada transaksi pertama atau TID 1 itemnya adalah $\{$ PTI,SIPOU $\}$ yang kemudian membuat simpul \{PTI,SIPOU\}. Sehingga terbentuk lintasan Null- PTI, SIPOU Pembentukan FP Tree dari TID 1 yang berisikan \{PTI,SIPOU $\}$ pembacaan TID 1 dapat dilihat pada gambar 3. lalu dilanjutkan dengan pembacaan TID 2 .

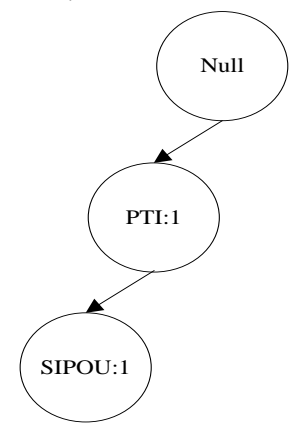

Gambar 3 Hasil Pembentukan FP Tree Setelah Pembacaan TID 1

Pembacaan TID 2

Pada transaksi kedua atau TID 2 itemnya adalah \{MSQL\} penambahan support count pada simpul yang ada. Pembacaan TID 2 dapat dilihat pada gambar 3 yang akan dilanjutkan pembacaan TID 3 .

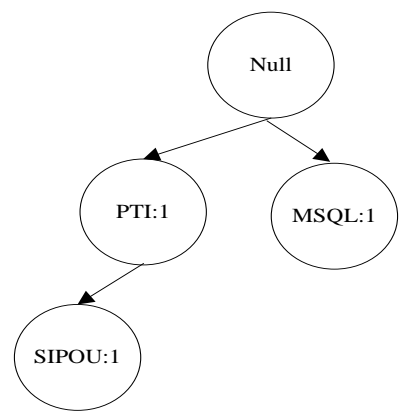

Gambar 4 Hasil Pembentukan FP Tree setelah Pembacaan TID 2

Pembentukan TID 3

Pada transaksi ketiga atau TID 3 itemnya adalah \{MSQL\}, penambahan support count pada lintasan yang sudah ada, pembacaan TID 3 dapat dilihat pada gambar 4, yang akan dilanjutkan pembacaan TID 4.

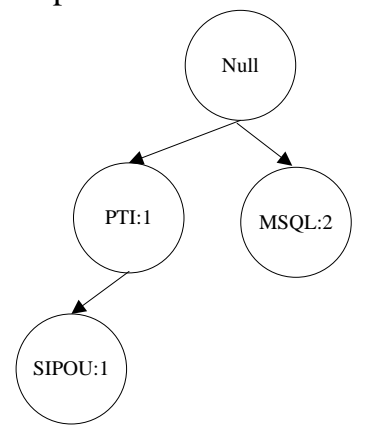

Gambar 5 Hasil Pembentukan FP Tree setelah Pembacaan TID 3

Pembacaan TID 4

Pada transaksi keempat atau TID 4 itemnya adalah \{MSQL,PTI,SIPOU\} yang kemudian, pembentukan FP Tree dari TID 4. dapat dilihat pada gambar 6 . 
IN F ORM A I K A

Jurnal Informatika, Manajemen Dan Komputer Vol. 9 No. 1, Mei 2017

eISSN : 2580-3042

pISSN : 1979-0694
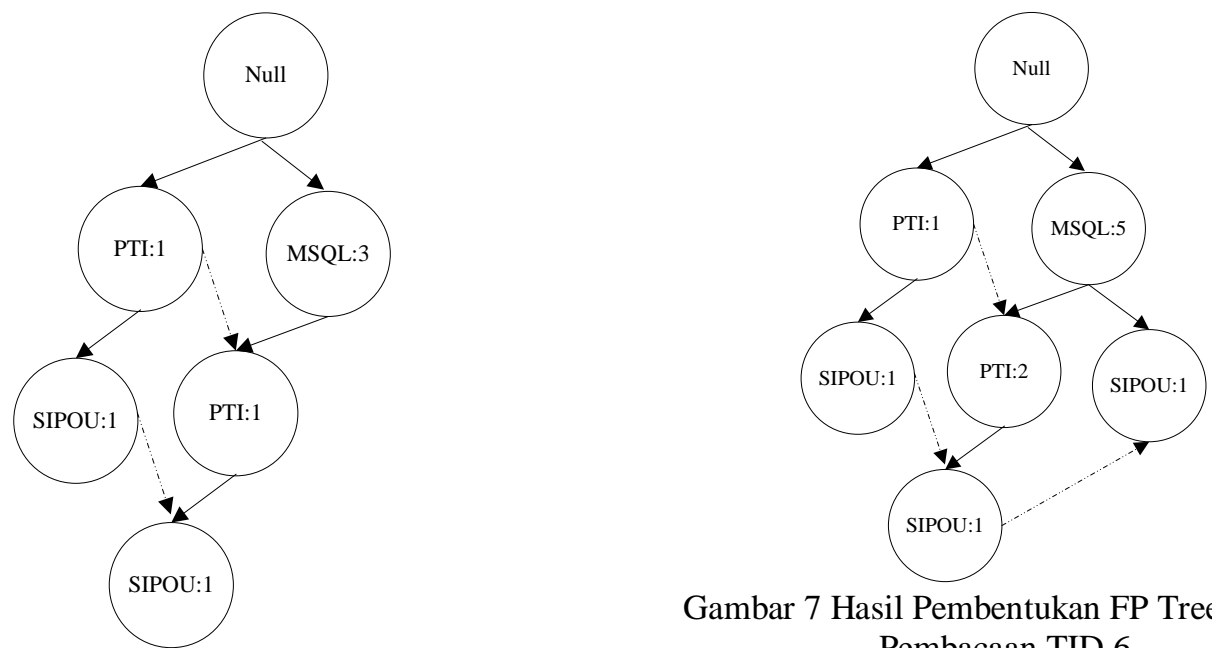

Gambar 7 Hasil Pembentukan FP Tree setelah Pembacaan TID 6

Gambar 6 Hasil Pembentukan FP Tree setelah Pembacaan TID 4

Pembacaan TID 5

Pada transaksi kelima atau TID 5 itemnya adalah $\{$ MSQL,SIPOU , pembentukan FP Tree dari TID 5 penambahan support account pada item SIPOU. Pembacaan TID 5 dapat dilihat pada gambar 6 yang akan dilanjutkan pembacaan TID 6 .

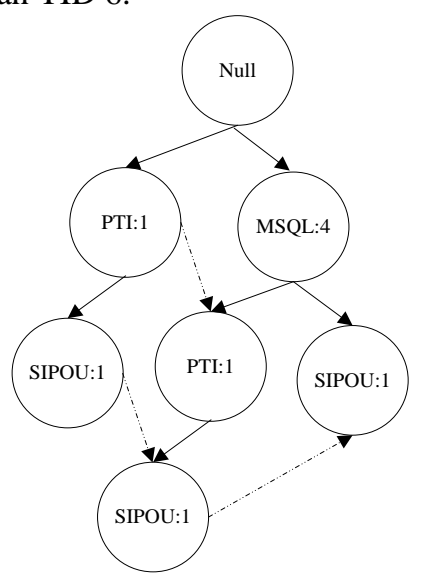

Gambar 6 Hasil Pembentukan FP Tree setelah Pembacaan TID 5

Pembacaan TID 6

Pada transaksi keenam atau TID 6 itemnya \{MSQL,PTI\}, pembentukan FP Tree dari TID 5 pembentukan Support Account pada item MSQL, PTI. Pembacaan TID 6 dapat dilihat pada gambar 7 yang akan dilanjutkan pembacaan TID 7

Pembacaan TID 7

Pada transaksi ketujuh atau TID 7 itemnya adalah $\{\mathrm{PTI}\}$ yang menambah support count pada simpul PTI. Pembentukan FP Tree dari TID 7 dapat dilihat pada gambar 8

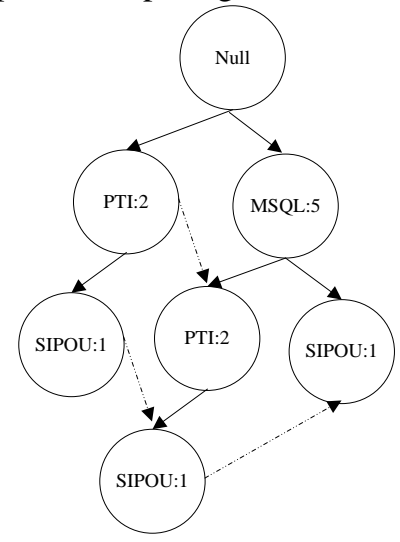

Gambar 8 Hasil Pembentukan FP Tree setelah Pembacaan TID 7

Pembacaan TID 8

Pada transaksi ketujuh atau TID 7 itemnya adalah $\{$ MSQL,PTI $\}$ yang menambah support count pada simpul PTI. Pembentukan FP Tree dari TID 7 dapat dilihat pada gambar 9 
IN F ORM A I K A

Jurnal Informatika, Manajemen Dan Komputer Vol. 9 No. 1, Mei 2017

eISSN : 2580-3042

pISSN : 1979-0694

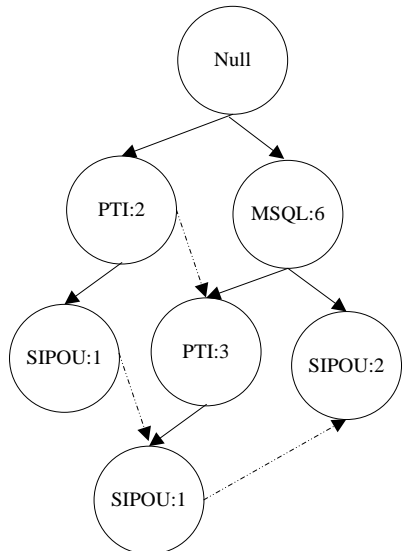

Gambar 9 Hasil Pembentukan FP Tree setelah Pembacaan TID 8

Pembacaan TID 9

Pada transaksi ketujuh atau TID 8 itemnya adalah $\{$ MSQL,PTI $\}$ yang menambah support count pada simpul PTI. Pembentukan FP Tree dari TID 8 dapat dilihat pada gambar 10

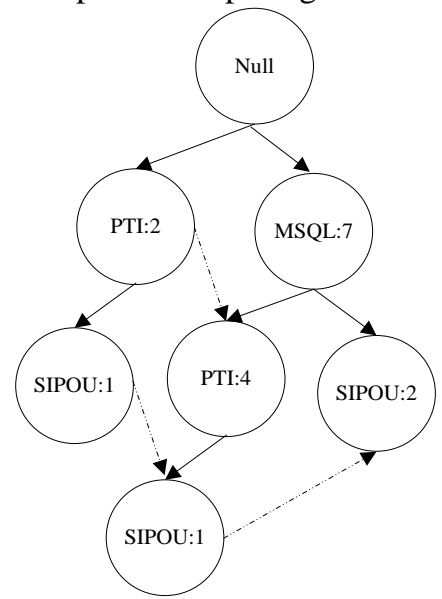

Gambar 10. Hasil Pembentukan FP Tree setelah Pembacaan TID 9

Pembacaan TID10

Pada transaksi ketujuh atau TID 9 itemnya adalah $\{\mathrm{PTI}\}$ yang menambah support count pada simpul PTI. Pembentukan FP Tree dari TID 9 dapat dilihat pada gambar 11 .

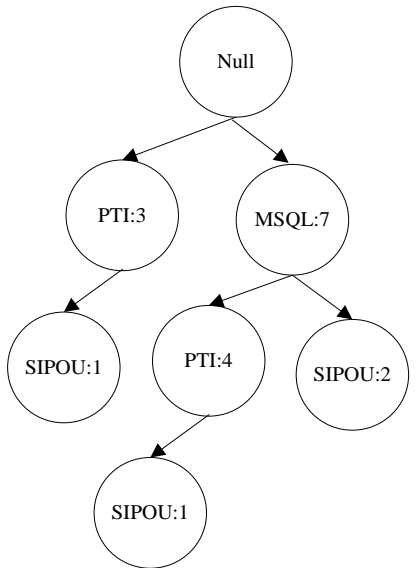

Gambar 11 Hasil Pembentukan FP Tree setelah Pembacaan TID 10

\subsection{Penerapan FP Growth}

Setelah dilakukan Pembangunan FP Tree dari sekumpulan transaksi yang telah dilakukan, pada tahapan diatas maka dilanjutkan dengan tahap $\mathrm{Fp}$ Growth untuk mencari Frequent itemset yang memenuhi syarat. Langkah $F p$ Growth ini sebanyak 3 langkah utama yaitu Conditional Pattern Base, pembangkitan Conditional FP Tree, dan pencarian Frequent itemset.

\subsection{Pembangkitan Conditional attern Base}

Setelah mencari frequent itemset untuk beberapa akhiran (suffix). Pada tahap pembangkitan conditional pattern base dilakukan dengan cara upapohon atau ditentukan dengan cabang pohon dengan support count terkecil, yaitu SIPOU,PTI,MSQL. Untuk membangkitkan conditional pattern base, dari lintasan FP Tree dapat diambil lintasan yang mengandung suffix MSQL. Hal ini akan dijelaskan pada tabel berikut ini.

Tabel 4. Pembangkitan Conditional Pattern

\begin{tabular}{ll}
\multicolumn{2}{c}{ Base } \\
\hline TID & Conditional Pattern Base \\
\hline SIPO & $\{\{$ PTI: 1$\},\{$ MSQL:1 $\},\{$ MSQL:1,PTI: \\
U & $1\}\}$ \\
PTI & $\{$ MSQL: 1$\}$ \\
\hline
\end{tabular}

3.6. Pembangkitan Conditional FP-Tree Setelah tahap pembangkitan conditional pattern base dilakukan maka langkah selanjutnya adalah tahap pembangkitan conditional FP Tree. Pada tahap ini juga dilakukan dengan melihat FP Tree yang sudah dibentuk sebelumnya. Conditional FP Tree 
I N F O R M A T I K A

Jurnal Informatika, Manajemen Dan Komputer Vol. 9 No. 1, Mei 2017

eISSN : 2580-3042

pISSN : 1979-0694

dimaksudkan untuk mencari frequent itemset yang berakhiran item tertentu atau mengandung suffix yang sama.

Dari hasil pembentukan FP Tree sebelumnya maka langkah pertama yang dilakukan adalah membangkitkan conditional FP Tree untuk lintasan yang mengandung suffix SIPOU. Tahap ini setaip lintasan yang memiliki simpul SIPOU dibuang, hal ini dapat dilihat pada gambar 12

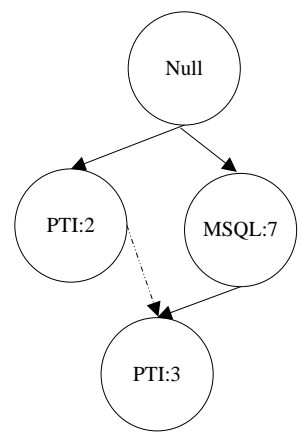

Gambar 12. Conditional FP-Tree dengan suffix SIPOU

Tahap selanjutnya adalah membangun Conditional FP Tree setiap lintasan yang mengandung suffix $\{\mathrm{PTI}\}$ seperti pada gambar 13

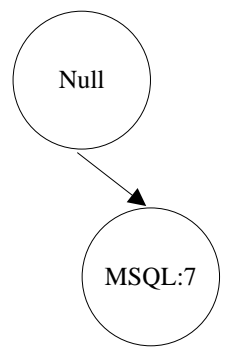

Gambar 13. Conditional FP-Tree dengan suffix PTI

\subsection{Pencarian Frequent Itemset}

Setelah memeriksa Frequent itemset untuk akhiran (suffix), maka dapatlah hasil secara keseluruhan yang terlihat dalam tabel 4 .

Tabel 4 Pencarian Frequent Itemset

\begin{tabular}{ll}
\hline Suffix & Frequent itemset \\
\hline SIPO & $\{$ SIPOU,$\{$ PTI,SIPOU,$\{$ MSQL, SIP \\
U & OU $\}$ \\
PTI & $\{$ PTI $\},\{$ MSQL,PTI $\}$ \\
MSQ & $\{$ MSQ $\}$ \\
L & \\
\hline
\end{tabular}

Pencarian Association Rules dilakukan melalui dua tahap yaitu pencarian frequent itemset dan penyusutan rules. Penting tidaknya suatu Association Rules dapat diketahui dengan dua parameter, yaitu support (nilai penunjang) dengan nilai min support $30 \%$ dan confidence (nilai kepastian) dengan minimum confidence $50 \%$. Support adalah ukuran yang menunjukan tingkat dominasi itemset dari kesuluruhan transaksi.

Setelah didapat frequent itemset, selanjutnya membuat rules dengan cara menghitung confidence dari tiap kombinasi rule. Dari 10 itemset yang dihasilkan pada tabel 4.9 tidak semua dihitung karena rule yang dihasilkan adalah jika A maka B, sehingga itemset yang dihitung minimal berisi dua item. Maka yang dihitung confidence-nya adalah 3 subsets, yaitu :

\{PTI,SIPOU $,\{$ MSQL,SIPOU $\},\{$ MSQL,PTI Hanya kombinasi yang lebih besar atau sama dengan minimum confidence yang akan diambil atau strong association saja. Rumus untuk menghitung Support dan Confidence menggunakan rumus:

$$
\text { support }=P(A \cap B)=\frac{\text { jumlah transaksi yang mengandung } A \text { dan } B}{\text { jumlahtotal transaksi }} \times 100 \%
$$

Confidence dari association rule adalah ukuran ketepatan suatu rule, yaitu persentase transaksi dalam database yang mengandung $\mathrm{A}$ dan mengandung

B. Confidence $=\frac{\text { jumlah transaksi yang mengandung A dan } B}{\text { jumlahtotal transaksi }} \times 100 \%$

Dari perhitungan nilai support setiap association rule yang dilalui, maka didapat hasil yang dapat dilihat pada tabel 5 Secara keseluruhan yang terlihat dalam tabel 5

Tabel 5 Hasil dan Analisa Association Rule

\begin{tabular}{|c|c|c|c|c|c|c|c|c|}
\hline $\begin{array}{l}\mathbf{N} \\
\mathbf{0}\end{array}$ & \multicolumn{3}{|c|}{$\begin{array}{l}\text { Kombi } \\
\text { nasi }\end{array}$} & $\begin{array}{c}\text { Su } \\
\text { ppo } \\
\text { rt } \\
\text { A } \\
(\% \\
)\end{array}$ & $\begin{array}{c}\text { Suppo } \\
\text { rt } \\
\mathbf{A} \stackrel{B}{\longrightarrow}\end{array}$ & \multicolumn{2}{|c|}{$\begin{array}{l}\text { Confid } \\
\text { ence } \\
(\%)\end{array}$} & \multirow[t]{2}{*}{$\begin{array}{l}\text { Sta } \\
\text { tus }\end{array}$} \\
\hline & & & $S$ & & & & & \\
\hline & & & I & & & & & \\
\hline & $\mathrm{P}$ & & $\mathrm{P}$ & & & 2 & & \\
\hline & $\mathrm{T}$ & & $\mathrm{O}$ & $7 / 1$ & & 0 & 29 & \\
\hline 1 & I & $\rightarrow$ & $\mathrm{U}$ & 0 & $70 \%$ & $\%$ & $\%$ & No \\
\hline & $\mathrm{S}$ & & & & $30 \%$ & 2 & & \\
\hline & I & & $\mathrm{P}$ & & & 0 & & \\
\hline & $\mathrm{P}$ & & $\mathrm{T}$ & $3 / 1$ & & $\%$ & 67 & \\
\hline 2 & $\mathrm{O}$ & & I & 0 & & & $\%$ & Yes \\
\hline
\end{tabular}


I N F O R M A T I K A

Jurnal Informatika, Manajemen Dan Komputer Vol. 9 No. 1, Mei 2017

eISSN : 2580-3042

pISSN : 1979-0694

$\mathrm{U}$

\begin{tabular}{|c|c|c|c|c|c|c|c|}
\hline & & $S$ & & $70 \%$ & 2 & & \\
\hline & $\mathrm{M}$ & I & & & 0 & & \\
\hline & $S$ & $P$ & & & $\%$ & & \\
\hline & Q & $\mathrm{O}$ & $7 / 1$ & & & 29 & \\
\hline 3 & L & $\rightarrow \mathrm{U}$ & 0 & & & $\%$ & No \\
\hline & $S$ & & $7 / 1$ & $70 \%$ & 2 & & \\
\hline & I & M & 0 & & 0 & & \\
\hline & $P$ & S & & & $\%$ & & \\
\hline & $\mathrm{O}$ & Q & & & & 29 & \\
\hline 4 & $\mathrm{U}$ & $\rightarrow \mathrm{L}$ & & & & $\%$ & No \\
\hline & M & & $7 / 1$ & & & & \\
\hline & $S$ & $\mathrm{P}$ & 0 & & 4 & & \\
\hline & Q & $\mathrm{T}$ & & & 0 & 57 & \\
\hline 5 & $\mathrm{~L}$ & $\rightarrow \mathrm{I}$ & & $70 \%$ & $\%$ & $\%$ & Yes \\
\hline & & N & $7 / 1$ & & & & \\
\hline & $\mathrm{P}$ & $S$ & 0 & & 4 & & \\
\hline & $\mathrm{T}$ & $\mathrm{Q}$ & & & 0 & 57 & \\
\hline 6 & I & $\rightarrow \mathrm{L}$ & & $70 \%$ & $\%$ & $\%$ & Yes \\
\hline
\end{tabular}

Berdasarkan hasil pengujian dan analisa Assoction Rule menggunakan Rapidminer Studio 7.3. Jadi jumlah Rules keseluruhan yang telah diproses adalah 6 keputusan atau pengetahuan baru dengan nilai kombinasi 2 jenis buku, nilai Support A (\%) dengan Confidence $\geq 50 \%$ "Yes" dan $\leq 50 \%$ "No".

Tabel 6 Perhitungan Nilai Support Setiap

\begin{tabular}{cccc}
\multicolumn{3}{c}{ Association Rule } \\
\hline No & Jika & Maka & Support \% \\
\hline \multirow{2}{*}{1} & \multirow{2}{*}{ MSQL } & PTI & $4 / 10=0.4=$ \\
& & & $40 \%$ \\
2 & \multirow{2}{*}{ PTI } & MSQL & $4 / 10=0.4=$ \\
& & & $40 \%$ \\
\hline
\end{tabular}

Adapun perhitungan nilai Confidence setiap association rule yang dilalui maka diperolehlah hasil secara ke seluruhan yang terlihat dalam tabel 7

Tabel. 7 Perhitungan Confidence Setiap Assosiation Rule

\begin{tabular}{clll} 
No & Jika & Maka & Confidence \\
\hline 1 & MSQL & PTI & $40 \% / 70=57 \%$ \\
2 & PTI & MSQL & $40 \% / 70=57 \%$
\end{tabular}

Setelah diketahui hasil support dan confidence, maka digabungkan hasilnya seperti dapat kita lihat pada tabel 8 hasil dari evaluasi keseluruhan association rule yang didapat.
Tabel 8 Perhitungan Nilai Support dan

Confidence Setiap Association Rule

\begin{tabular}{|c|c|c|c|c|}
\hline $\begin{array}{l}\mathbf{N} \\
\mathbf{0}\end{array}$ & Jika & Maka & $\begin{array}{c}\text { Suppor } \\
t \%\end{array}$ & $\begin{array}{c}\text { Confidenc } \\
e\end{array}$ \\
\hline 1 & $\begin{array}{l}\text { MSQ } \\
\text { L }\end{array}$ & PTI & $40 \%$ & $57 \%$ \\
\hline 2 & PTI & $\begin{array}{l}\text { MSQ } \\
\text { L }\end{array}$ & $40 \%$ & $57 \%$ \\
\hline
\end{tabular}

\section{Simpulan}

Dari tahap-tahap yang telah dilakukan di atas, maka dapat diambil kesimpulan sebagai berikut:

Tabel 9 Hasil Association Rule

\begin{tabular}{|c|c|}
\hline Rule & Keterangan \\
\hline Rule 1: & $\begin{array}{l}\text { Jika buku My SQL untuk Pemula } \\
\text { dipinjam maka buku Pengenalan } \\
\text { Teknologi Informasi akan } \\
\text { dipinjam dengan tingkat keinginan } \\
57 \% \text {. }\end{array}$ \\
\hline Rule 2 & $\begin{array}{l}\text { Jika buku Pengenalan Teknologi } \\
\text { Informasi dipinjam maka buku } \\
\text { My SQL Untuk Pemul akan } \\
\text { dipinjam dengan tingkat keinginan } \\
57 \% \text {. }\end{array}$ \\
\hline
\end{tabular}

Jadi jumlah Rules keseluruhan yang telah diproses adalah 2 keputusan atau pengetahuan baru. Setelah didapat Rules berarti telah selesai proses dari pengolahan Data mining untuk mendapat keputusan dalam mengklasifikasi transaksi peminjaman buku perpustakaan STMIK - AMIK Dumai. Berdasarkan hasil dari Rules dapat dilihat jenis Buku mana yang menjadi prioritas atau tidak prioritas untuk dapat dikembangkan di perpustakaan SMTIK - AMIK Dumai, dan Rules menjadi dasar atau tolak ukur dalam mengambil keputusan untuk kepentingan tertentu dalam penyelenggaraan menentukan jenis buku apa yang paling diminati pada perpustakaan SMTIK - AMIK Dumai.

\section{Referensi}

Abdullah, D, Erliana, I, C \& Juliana,( 2015), Implementasi Metode Rough Set Untuk Menentukan Data Nasabah Potensial Mendapatkan Pinjaman, SENATKOM, ISSN : 2460-4690. Hal:,

Anas, A, (2016), Analisa algorithma apriori Untu mendapatkan pola peminjaman buku perpustakaan smpn 3 batanghari, MEDIA SISFO, ISSN : 1978-8126, Vol. 10, No. 2., Hal: 282-295. 
IN F ORMA T I K A

Jurnal Informatika, Manajemen Dan Komputer Vol. 9 No. 1, Mei 2017

eISSN : 2580-3042

pISSN : 1979-0694

Arisandi, D, Nofriandi,(2016), Analisa pola pemilihan program studi Bagi calon mahasiswa di universitas abdurrab menggunakan association rule, UNIVRAB, ISSN : 2477-2062, Vol. 1, No. 1., Hal:, 89-90

Dahlan, A., Utami, E., \& Luthfi, T, T., (2013). Perancangan Data Warehouse Perpustakaan Perguruan Tinggi Xyz Menggunakan Metode Snowflake Schema.INFORMATIKA, ISSN : 19072430: Vol . 8, No 24, Hal:, 1-15

Ikhwan, A., \& Sriani., D, N., (2015). Penerapan Data mining dengan Algoritma FpGrowth untuk Mendukung Strategi Promosi Pendidikan (Studi Kasus Kampus STMIK Triguna Dharma), SAINTIKOM, ISSN : 1978-6603., Hal:, 221-226

Nasari, F, \& Darma, S,(2015), Penerapan $k$ means clustering pada data penerimaan mahasiswa baru (studi kasus : universitas potensi utama), TEKNOLOGI, ISSN : 2302-3805., Hal:, 2.1.

Meilani, D, B., \& Azinar, W, A., (2015) Penentuan pola yang sering muncul untuk penerima kartu jaminan kesehatan masyarakat (jamkesmas) Menggunakan metode fp-growth, TEKNOLOGI, ISSN : 2089-1121., Hal:, 424-431

Sari, P, D., (2015), Data mining perkiraan produksi spanduk dengan algoritma apriori (studi kasus :Cv. Mentari persada medan), INFORMATIKA, ISSN : 23019425., Vol. 9, No.1, Hal:, 33-41.

Singh, J., Ram, H \& Dr. Sodhi, J.S., (2013) Improving Efficiency of Apriori Algorithm Using Transaction Reduction, INTERNASIONAL, ISSN : 2250-3153., Vol. 3., Hal:, 1-4

Triyanto, A, W, (2014), Association Rule Mining Untuk Penentuan Rekomendasi Promosi Produk, SIMETRIS, Vol. 5, No.2, Hal: 121-125

Wahyudi, N. E., (2013). Teknik Klasifikasi untuk Melihat Kecenderungan Calon Mahasiswa Baru dalam Memilih Jenjang Pendidikan Program Studi di Perguruan Tinggi. DINAMIKA, ISSN : 0854-9524 : Vol 18, No.1, Hal:, 55-64 